\title{
Dune vegetation dynamics from 1937 to 1976 in the Mlalazi-Richards Bay area of Natal, South Africa
}

\author{
P. J. WEISSER* and R. MÜLLER*
}

\section{ABSTRACT}

Dune vegetation changes were studied qualitatively with the aid of air photos taken in 1937, 1957 and 1976. Results were transferred to 1:10 000 scale maps. In 1937 roughly $80 \%$ of the dune forest habitat was occupied by planted fields and post cultivation seral stages such as Secondary Grasslands and Dwarf Shrubland, Secondary Scrub and Acacia karroo Woodland. In three areas, the vegetation cover had been completely destroyed and drift sands had formed. In the 1950's the trend of vegetation degradation was changed by the implementation of an afforestation programme by the Department of Forestry. The 1976 air photos indicate that the post cultivation seral stages of 1937 had been largely replaced by forest plantations. In secondary, unafforested areas the vegetation is evolving rapidly towards a Secondary Dune Forest.

\section{RÉSUMÉ}

DYNAMIQUE DE LA VÉGÉTATION DES DUNES DE 1937 À 1976 DANS LA RÉGION DE MLALAZI-RICHARDS BAY AU NATAL, AFRIQUE DU SUD

\begin{abstract}
Les changements dans la végétation des dunes ont été étudiés qualitativement à l'aide de photographies aériennes prises en 1937, 1957 et 1976. Les résultats furent reportés sur des cartes à l'échelle de 1:10000. En 1937, approximativement $80 \%$ de l'habitat des forêts de dunes étaient occupés par des champs cultivés et des stades d'évolution post-culturale tels que des formations herbeuses secondaires et une formation arbustive naine, une formation broussailleuse secondaires et une forêt claire à Acacia karroo. Dans trois régions, la couverture végétale était détruite et des dunes mobiles s'étaient formées. Dans les années 50, le tendance vers une dégrádation de la végétation se modifia par la mise en oeuvre d'un programme de reboisement par le Département des forêts. Les photographies aériennes de 1976 indiquent que les stades d'évolution post-culturale de 1937 avaient été, pour la plupart, remplacés par des pluntations forestières. Dans les zones secondaires, non reboisées, la végétation évolue rapidement vers une forêt de dune secondaire.
\end{abstract}

\section{INTRODUCTION}

Huntley (1977), in reviewing terrestrial ecology in South Africa, indicated that whereas considerable progress had been made in mapping our country's vegetation, little effort had been made to obtain information on vegetation trends. This work aims to provide information in this field.

The objectives of this study of the MlalaziRichards Bay area of Natal were: (1) to provide an inventory of mapping units as determined from air photos; (2) to produce $1: 10000$ vegetation maps that could serve for management and vegetation monitoring purposes; and (3) to study vegetation changes and their causes, by using historic photos taken in 1937 and 1957.

Aerial photography has been used before to show qualitative changes and trends in coast-dune and estuarine ecology in the Natal coastal region (Ward, 1971 vide Edwards, 1972) and Weisser \& Marques (1979).

\section{STUDY AREA}

The coastal zone between Richards Bay Sanctuary and Mlalazi Estuary is a vegetated strip of dunes 28 $\mathrm{km}$ long, on the Natal Coast between $28^{\circ} 50^{\prime}$ and $28^{\circ} 57 \frac{1}{2}^{\prime}$ South and $31^{\circ} 46 \frac{1}{2}^{\prime}$ and $32^{\circ} 03^{\prime}$ East (Fig. 1). The maximum width of the dune field is $2250 \mathrm{~m}$, averaging about $1500 \mathrm{~m}$ and the area covers about

* Botanical Research Institute, Department of Agriculture, Private Bag X101, Pretoria 0001, South Africa.
3300 ha. The highest dune reaches $79 \mathrm{~m}$ above sea level.

The coastal dune soils (vide Venter, 1972) are predominantly sandy, and the climate is humid and warm to hot with a high year-round rainfall (Schulze, 1965). The mean annual temperature at the Cape St Lucia Station is $21,5^{\circ} \mathrm{C}$ and the mean annual rainfall at the Umhlatuzi Valley Sugar Estates near Richards Bay is $1106 \mathrm{~mm}$ (Venter, 1972). Prevailing winds are NE and SW. Plant growth is luxuriant and tropical. The region falls within the $20^{\circ} \mathrm{C}$ isotherm, which is accepted as the limit for tropical vegetation (Aubert de la Rue et al., 1958, in Venter, l.c.).

This dune area was part of Reserve 10, which was reallocated in 1952 to the Forestry Department under the Bantu Trust and Land Act, and handed over to Kwazulu on 1972-04-01 (Bower, MS.). Today the area falls under the jurisdiction of the Agriculture and Forestry Department of Kwazulu.

\section{METHODS AND MATERIALS}

Air photos were chosen as the main source of information as adequate material was available dating as far back as 1937. Mapping of the vegetation was done from air photos of Job 117-37 (1937, Trigonometrical Survey, Pretoria) and Job 251, University of Natal (1976) through direct inspection, enlargement and transference onto base maps using a Bausch \& Lomb ZT -4 Zoom Transfer Scope (ZTS). This instrument was also employed to draw the six base maps from ortho-photo maps. As no ortho-photo map was available at the time for the 


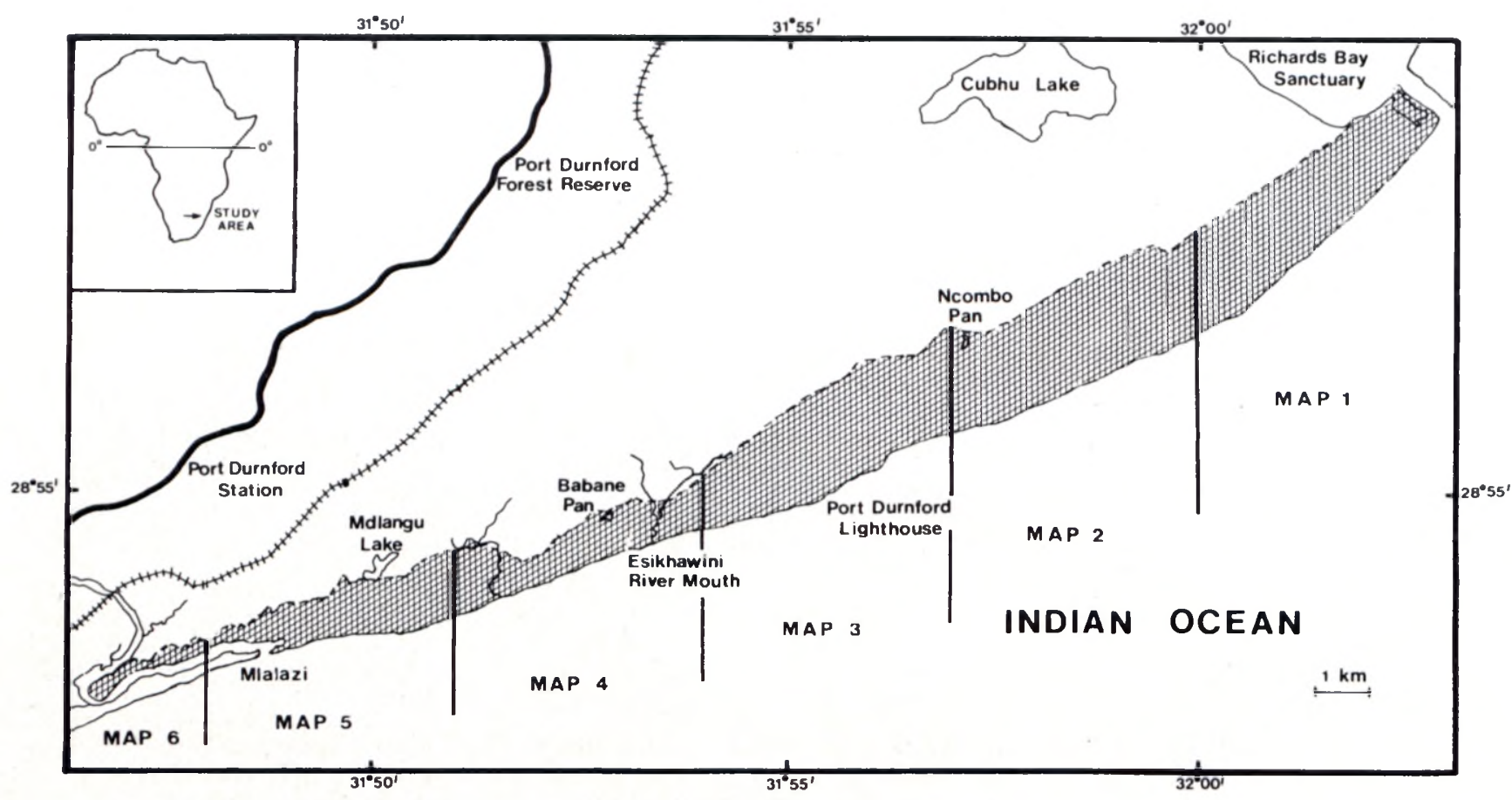

FIG. 1.-Location of study area (hatched) showing areas covered by the six maps.

Mlalazi Peninsula, the base map for that area was drawn directly from air photos. Fig. 1 indicates the area covered by each map. Interpretation of the aerial photographs was aided by a Topcon Stereoscope. Areas were measured with a MOP-AM02 Image Analyser. Ground truth and additional field data were gathered during 1979-1981.

Mapping units were based on air-photo interpretation and available field information. The 1937 vegetation maps were taken as the base line from which to monitor changes.

The photos used in the study were of different scales, varied quality and were taken under different conditions. No field data are available for checking the interpretation of the photos of 1937. These factors make comparison between different sets of air photos difficult. The advantages and disadvantages of the use of air photos for vegetation studies has been reviewed by Edwards (1972) and Weisser (1979).

Because of air photo distortion, the positioning of vegetation patches on the maps is only approximate. The air photos were realigned as soon as a deviation of corresponding points and areas was observed, while mapping was being done.

\section{RESULTS}

\section{Mapping units, inventory and vegetation trends}

Fifteen mapping units were identified by air-photo interpretation. A short description of them, their location, the trends observed and the inferred future development for the main mapping units follows. A more detailed description of the mapping units, and quantification of the vegetation changes is in preparation (Weisser, MS.). Additional information on the vegetation of the Richards Bay section of the study area is provided by Venter (1972).

\section{Beach}

In this mapping unit, the interface between sea and dunes was mapped. Interrupted by only two rocky outcrops, it forms an almost continuous band between the Richards Bay Sanctuary Mouth and Mlalazi Estuary. Dune pioneer communities may occasionally have been included in this unit, where they were masked by reflection from the beach sand.

Air-photo interpretation and field inspection showed one coastal erosion zone with narrow beaches and slumping dunefront (Fig. 2) in between two sand accretion zones with wide beaches. The first sand accretion zone extends from Richards Bay Sanctuary Mouth to about $4 \mathrm{~km}$ south and the second extends from Mlalazi Estuary northwards for about $4,5 \mathrm{~km}$, whereas the retreating coast lies between these areas.

The greatest accretion was found north of the Mlalazi Estuary, where the beach advanced about 70 metres from 1937 to 1976 . This sand accumulation could be related to agricultural malpractices in the catchment area that lead to an increase of sediments brought to the sea by the Tugela and Mlalazi Rivers.

\section{Littoral drift sands}

Drift sands that originate on the beach form tongues into the vegetated dunes. Keet (1936) and Stephens (1939) maintain that many drift sands start as cattle paths which expose the sand to the wind after the vegetation has been destroyed. Many drift sands were too small to be mapped, because their size was less than the mapping resolution. The position of the drift sands was reasonably constant through the years along the coast, and they often provided useful matching points during mapping.

By comparing 1937 and 1976 maps, a reduction in size and number of coastal drift sands was found. 
Fig. 2.-Undercutting by the sea and slumping of dune barrier is common. Pioneer communities frequently establish themselves on newly exposed surfaces (January, 1979).

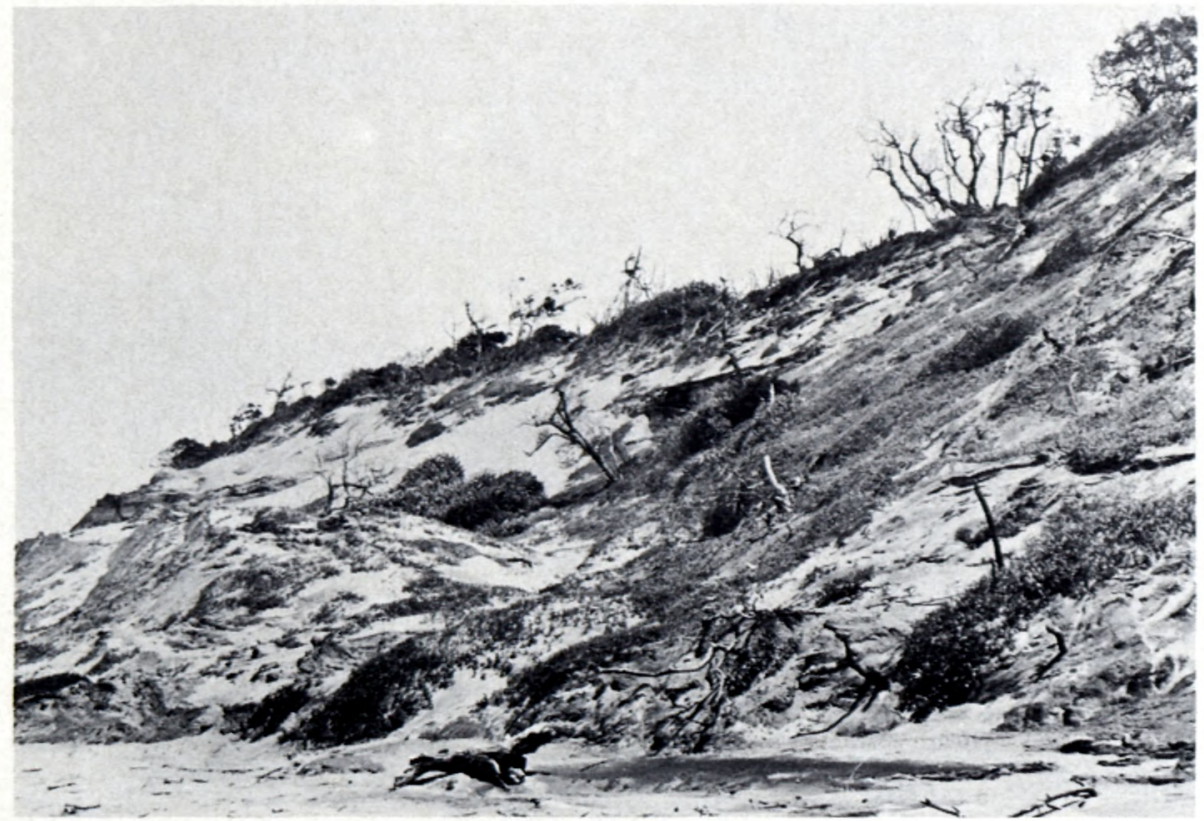

This was probably a consequence of the protective management (e.g. reduction of grazing and fire) carried out by the Department of Forestry and of their drift sand rehabilitation programme using Casuarina equisetifolia.

\section{Inland drift sands}

Three main inland drift sands were found on the 1937 photographs. On the 1976 photos they were found to have stabilized mainly through the plantings of Casuarina equisetifolia (Fig. 5).

Under present management, there is no danger of drift sands recurring. However, their presence in 1937 is a warning of the potential dangers inherent in the abuse of the area.

\section{Sand and clay quarries}

These bare areas have arisen because of quarrying activities.

\section{Dune Pioneers}

This community is present adjacent to the northern and southern beaches of the study area. The main plant is Scaevola thunbergii, which is essential in the dune build-up as sand collects around its branches. Other common plants are Arctotheca populifolia and Gazania rigens var. uniflora.

Since 1937 the area occupied by this community has increased, because new areas suitable for dune pioneers have formed at the Richards Bay New Mouth area and along the southern part of the coast. Consistent mapping of this community from air photos is difficult because it is sometimes masked by intense reflection from the beach sand. The poorer quality of the air photos of 1937 impairs comparison with the photos of 1976 .

\section{Passerina rigida Low Scrub}

This community follows the dune pioneer community in the succession and is characterized by the presence of the shrub Passerina rigida. In 1976 it formed a 1,5 km long band of vegetation between the Dune Pioneers and the Closed Dune Scrub north of the Mlalazi Estuary Mouth. Since 1937 this vegetation band has been displaced seawards by about $30 \mathrm{~m}$. The landward side of the band has been invaded by Closed Dune Scrub and seawards, this community has encroached onto the Dune Pioneer Community. This denotes the advance of succession and is similar to that reported from south of the Mlalazi Mouth (Moll, 1972; Weisser et al., 1982) and other parts of Natal e.g. Isipingo (Ward, 1980). As primary succession proceeds, a slow seaward expansion of this community can be expected, whereas on the landward side an encroachment of Closed Dune Scrub into the $P$. rigida Scrub will occur.

A future expansion of this community will depend on the availability of areas of Dune Pioneer Community that can be invaded. If, as is expected, the sand supply for this coastal zone increases and a consequent increase of Coastal Dune Pioneer communities results, an increase in area of this scrub community will take place.

\section{Cultivation, old lands and Secondary Mixed Dune Grassland and Dwarf Shrubland}

This mapping unit covered the largest area in 1937. This was the result of destruction of the original forest by humans, through fire, clearing of forest for cultivation and grazing. The 1957 air photos show a reduced area of this mapping unit, whereas in 1976 only isolated, minor patches are present.

The mapping unit presents a varied picture, such as cultivated fields, old lands, grasslands dominated by grasses such as Imperata cylindrica to a dwarf shrubland with species such as Chrysanthemoides monilifera and Helichrysum spp. Secondary succession of the complex of communities included in this mapping unit will in time lead to Secondary Acacia karroo Woodland or a Secondary Dune Scrub and a Secondary Dune Forest (Fig. 5). 


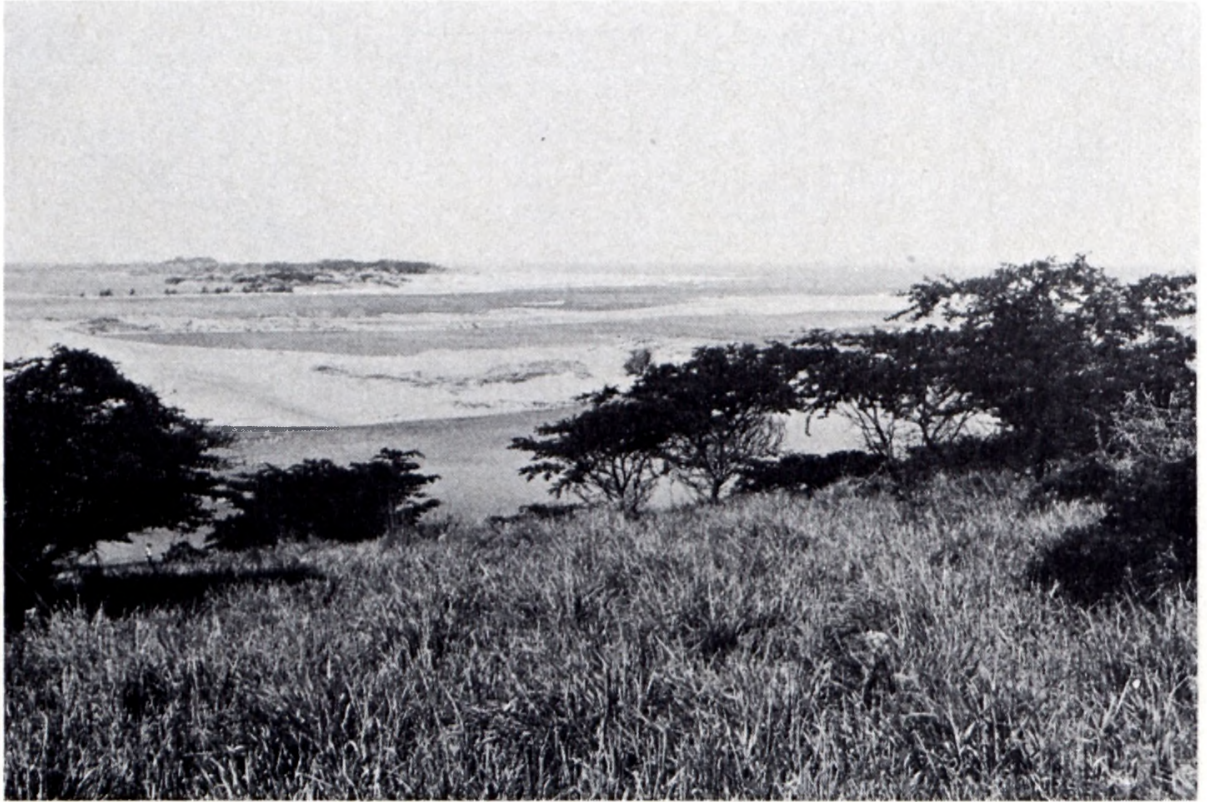

Fig. 3.-New mouth region (Map 1) of the Richards Bay Sanctuary, with sand areas colonized by dune pioneers (centre). The Secondary Dune Grassland shows an invasion by Acacia karroo that will form a woodland later.

After the control of this area was taken over by the Department of Forestry during 1952, most of the area classified in this mapping unit was afforested with Pinus and Eucalyptus and Casuarina equisetifolia was planted in rows as wind breaks (Fig. 5).

Areas not afforested are, in the absence of fire, grazing and ploughing, rapidly invaded by woody vegetation such an Acacia karroo Woodland (Fig. $3)$, including species such as Allophyllus natalensis, Clerodendron glabrum, Rhus nebulosa and Apodytes dimidiata.

If present management conditions persist, the secondary grasslands and dwarf shrublands will disappear and be replaced mainly by Acacia karroo Woodland, Secondary Scrub and Secondary Forest. This conclusion was also reached by Weisser (1978a) for the grasslands north of Richards Bay.

8. Secondary Acacia karroo or Trema orientalis Woodland with occasional Secondary Scrub

As found in other areas (e.g. Edwards, 1967; Weisser, 1980) Acacia karroo is a frequent invader of abandoned fields, Secondary grassland (Fig. 3) and dwarf shrubland communities. During field checking, it was discovered that some areas at Richards Bay interpreted as Acacia karroo Woodland were in fact Trema orientalis groves. Therefore, Trema orientalis stands were included in this mapping unit. MacDonald \& Pammenter (MS.) reported Trema orientalis as the main woody species in the regeneration of a Coastal Dune Forest after fire. This suggests that the Trema orientalis areas found have been affected by fire.

Acacia karroo Woodland has occupied most of the habitat suitable for its development and only a slight increase of the Acacia karroo area is expected in the future. However, because Acacia karroo is a successional stage of development towards Secondary Dune Scrub and Forest, older parts will progressively be taken over and Acacia karroo Woodland will diminish under the present management (Fig. 5).

\section{Secondary Dune Scrub, Secondary Dune Forest} and Degraded Dune Forest

This is a complex mapping unit of primary and secondary forest areas, with limits that were difficult to map, especially in relation to the often adjacent Climax Dune Forest. This mapping unit is mainly found at the northern and southern end of the study area.

In the short term, under the present management, an increase of this unit can be expected, as old Acacia karroo Woodlands are replaced in the succession by Secondary Dune Forest. In the long term, a decrease will occur, when the Secondary Dune Forest evolves to Climax Dune Forest (Fig. 5).

\section{First Seaward Dune Slope, usually with Closed Dune Scrub and Low Forest}

This mapping unit forms an almost continuous band of woody vegetation along the coast and is exposed to seawinds on the usually steep seaward slope of the dunes. The canopy frequently shows windpruning owing to exposure to saltspray-bearing seawinds. The landward limit was established stereoscopically, taking the upper limit of the first seaward slope as the boundary. On eroding coastal stretches this mapping unit includes newly exposed substrates that tend to be colonized by pioneers (Fig. 2) and about 25 'arcuate scars' (vide Weisser, $1978 \mathrm{~b})$. These arcuate discontinuities in the dune barrier are caused by erosion when a water spring is present.

Since 1937, the area of this mapping unit increased at the expense of drift sands and decreased because of erosive processes in the central part of the study area. Dune slumping causes the destruction of Closed Dune Forest and, more rarely, of Climax Dune Forest (Fig. 2).

Where primary and seral stages of secondary vegetation are present today, a progression towards the climax is expected. Some areas may be affected by coastal erosion in the future. 


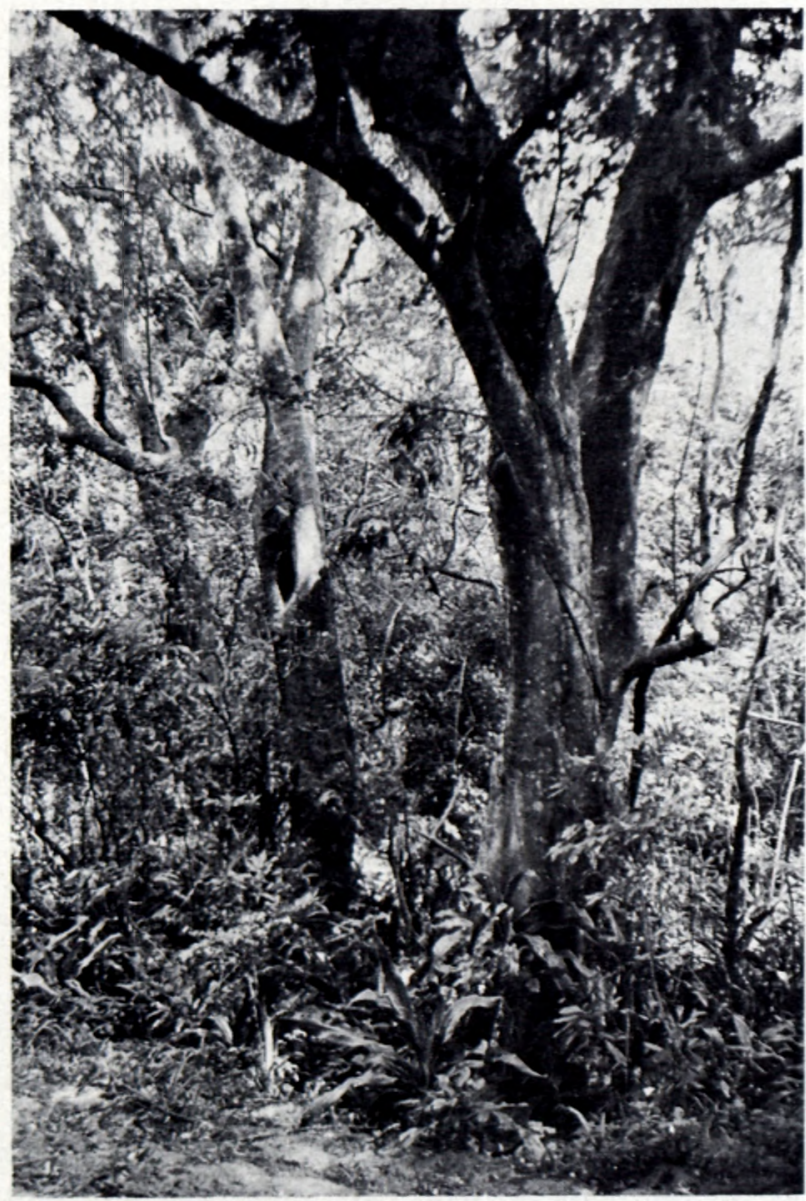

FIG. 4.-Dune Climax Forest on the road to the Richards Bay Sanctuary Mouth with tall Celtis africana trees and Dracaena hookeriana in the undergrowth.

\section{Climax Dune Forest}

The Climax Dune Forest (Fig. 4) consists of a few tall dominant trees with a poorly developed understorey and often dense fieldlayer with Isoglos$s a$ woodii. Additional information on this type of vegetation can be obtained from Venter (1972) and Weisser (1978 \& 1980).

Climax Dune Forest probably covered most of the study area before colonization by man. Relations with other mapping units are shown in Fig. 5. By 1976, owing to clearing for shifting cultivation and grazing, it had dwindled to an area of about 20 ha on the Mlalazi Peninsula, some minor isolated pockets mainly near the coast and some forest areas near Richards Bay.

The delimitation of this mapping unit from Secondary Dune Scrub and Secondary Forest is often difficult because they are similar on the air photos. Therefore the limits obtained must be regarded as tentative. The diminishing trend of this primary Dune Forest was stopped by conservative management of the Forestry Department as from 1952.

From the conservation point of view, this mapping unit is most important, as it represents what was typical for the dune before the advent of man in the area (Weisser, 1978b). If the present management for protection against human interference and fire continues, the area of climax forest will not be diminished.
Fig. 5.-Successions (solid lines), retrogressions (stippled lines), and afforestation (dashed lines) pathways as shown on aerial photos from 1937 to 1976 after clearing of Climax Dune Forest.

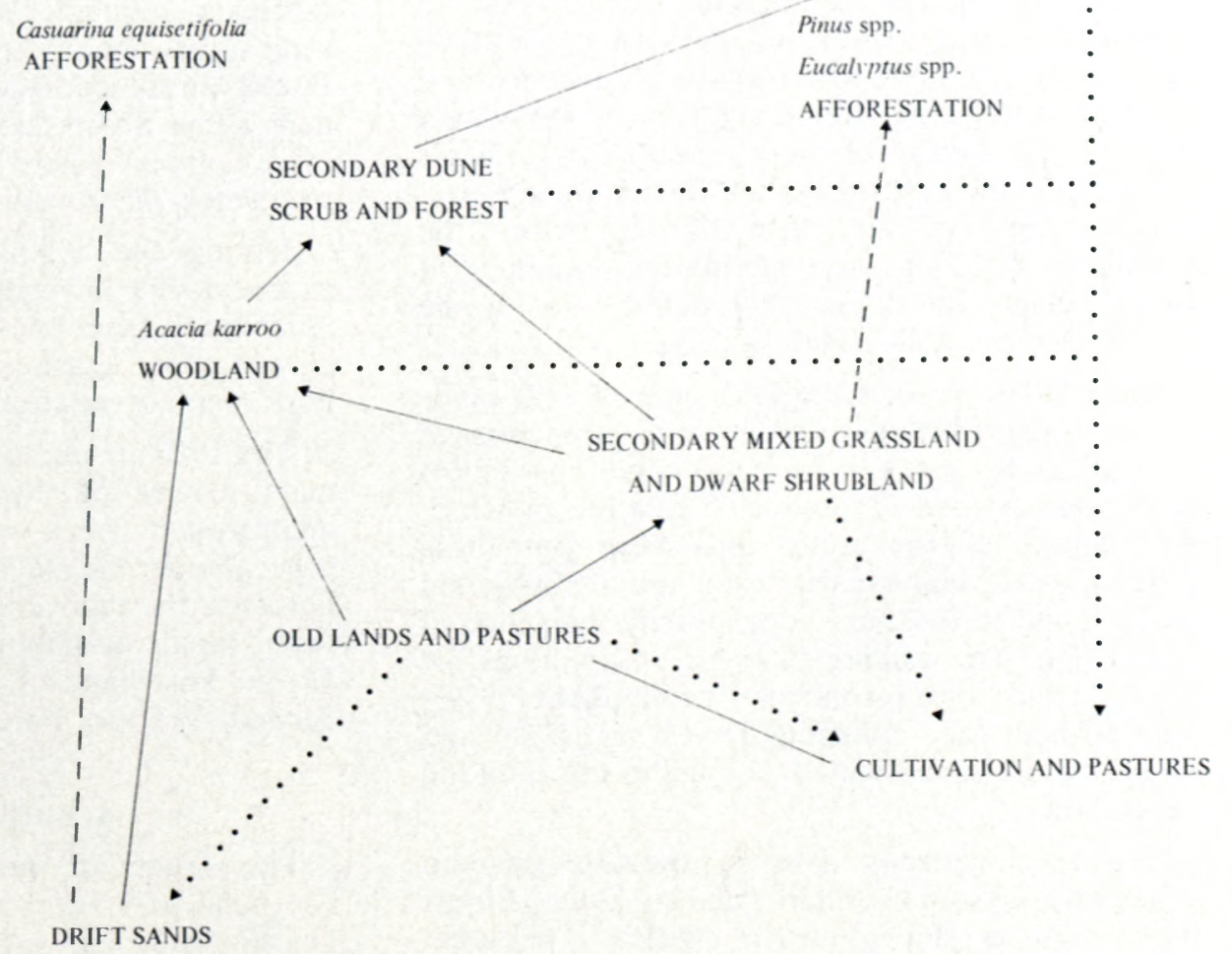




\section{Casuarina equisetifolia Afforestation}

Casuarina equisetifolia was extensively and successfully used to stabilize drift sands by planting it in rows as wind breaks. This mapping unit is mainly found on drift sands (Fig. 5).

Most areas suitable for this species have been planted and little or no increase in area is expected.

\section{Eucalyptus and Pinus Afforestation}

Most of the Secondary Mixed Grassland and Dwarf Shrubland of 1937 are today covered with Pinus and Eucalyptus forests (Fig. 5). The main plantations are located in the central portion of the study area.

A few areas suitable for afforestation are still available, and they will probably be used in the near future. However, if plans for a Botanical Garden for Kwazulu (K. Cooper, pers. comm.) are implemented, some areas will, after harvesting, be allowed to revert to communities with indigenous species.

\section{Kraal areas}

On the 1937 air photos $77 \mathrm{kraal}$ areas were detected. With the take-over by the Forestry Department, the people moved and no kraals were found on the air photos of 1976.

\section{Areas occupied by Forestry facilities}

These areas include human dwellings, firetowers and their surroundings belonging to the Department of Forestry and are of limited extent.

\section{Vegetation maps}

Six vegetation maps for 1937 and six for 1976 at a scale of 1: 10000 were completed and are available for inspection and use at the Botanical Research Institute.

\section{DISCUSSION AND CONCLUSIONS}

The presence of continuous dune forest in undisturbed dune areas south and north of the study area, at, for example Mtunzini and Mapelana, and the relics of Climax Dune Forest in the study area itself on the Mlalazi Peninsula and near Richards Bay support the hypothesis that Climax Dune Forest covered most of the dune barrier before the colonization of man. Iron age human settlement of the Zululand Coast probably dates back to the fourth century A.D. (Hall \& Vogel, 1978).

Keet (1936) reports the formation of drift sands owing to (1) cultivation on dunes; (2) trampling of vegetation by stock; (3) paths and roads; (4) veld-burnings; and (5) excessive clearing of scrub. Air photos of the study area bear out these observations. Many kraals, recent and old fields and paths found in the dune area provide evidence of occupation. The validity of these observations for the Zululand Coast is confirmed by Stephens (1939), who visited the Zululand Dunes in 1938 and described the human settlement and its effect on the vegetation.

Fig. 5 schematically represents the knowledge on vegetation dynamics after Climax Dune Forest destruction as shown on air photos. The great differences on the vegetation maps of 1937 and 1976 are the consequence of human occupation of the dunes. They are related to the needs of people for space, habitation, fuel wood, grazing lands and croplands. Because of the loss of fertility of the dune soils after a few years of cultivation, the inhabitants shifted and cleared new dune forest areas. In this way a large area was affected by a small population.

Abandonment of fields induced secondary, post cultivation plant successions. Many old lands were found covered with Acacia karroo Woodland, a Secondary Dune Scrub or Secondary Dune Forest.

These results are similar to those reported for the dune area at the Richards Bay-Mfolozi Mouth by Weisser \& Marques (1979) and confirm the high degree of vegetation degradation caused in the past by shifting cultivation, fire and grazing on the Zululand Coast. The rapid vegetation recovery through secondary plant successions, once protective measures by the Department of Forestry were enforced, was also confirmed.

The future of the vegetation will depend on the management applied to the area. If the Forestry Department of Kwazulu continues the management system applied since 1952, the plantation areas will continue to be used for afforestation and some Secondary Grassland and Secondary Shrubland areas will be additionally afforested. Acacia karroo Woodland will invade some of the grasslands and dwarf shrublands and, in time, develop into Secondary Dune Forest. Present-day Acacia karroo and Trema orientalis Woodlands will develop into Secondary Dune Forest. Secondary Dune Forest present today will mature becoming more like the original Dune Forest (Fig. 5).

Extensive vegetation changes since 1937 were found documented on air photos, an estimated $80 \%$ of the mapping units having changed since 1937. At the time, most of the Climax Dune Forest had been destroyed and replaced by fields and post cultivation seral stages, mainly Secondary Dune Grassland and Dwarf Shrubland, Acacia karroo Woodland, Secondary Dune Scrub and Secondary Dune Forest. In three places where the vegetation cover was completely destroyed, inland drift sands originated.

During the 1950's, the Forestry Department caused a shift in vegetation trends by removing the inhabitants from the dunes, enforcing protection against fire, grazing and further clearing, and implemented an afforestation programme.

The 1976 air photos show forest plantations as a main feature of the study area and secondary, unafforested areas with more dense vegetation cover. Under the management of the Department of Forestry, the recovery of secondary vegetation has been rapid, usually leading through an Acacia karroo Woodland of Secondary Dune Scrub to a Secondary Dune Forest.

\section{ACKNOWLEDGEMENTS}

The authors are indebted to Drs D. Edwards, J. C. Scheepers and O. A. Leistner, $\mathrm{Mr} \mathbf{M}$. O'Callaghan, Mrs J. N. Weisser and Misses A. P. 
Backer and L. Smith for their critical comments on the manuscript; also to Messrs W. de Waal, I. F. Garland and C. Buthelezi for their help during field work. Mr R. E. Crofts (Office of the Director General of Surveys); Prof. D. A. Scogings and $\mathrm{Mr}$ A. Bikaroo (Survey Department, University of Natal) for their help in obtaining aerial photographs; Mrs A. Romanowski for the photographic work; and Mesdames M. M. Loots, J. Mulvenna, S. Smit and N. Miller for typing. Special thanks are due to the Natal Parks, Game and Fish Preservation Board and personnel for their logistical support while in the field.

\section{REFERENCES}

BOWER. H., no date. Drifisand reclamation Zululand coast. Department of Forestry, KwaZulu, Eshowe.

EDwardS. D., 1967. A plant ecological survey of the Tugela River Basin. Mem. bot. Surv. S. Afr. No. 36.

EDWARDS. D., 1972. Remote sensing in the evaluation of the natural vegetation resources of South Africa. In Proceedings of the 5th Symposium on remote sensing, Pretoria, CSIR, May 1972, 99-102.

Hall. M. \& Vogel. J. C., 1978. Enkwazini: Fourth Century Iron Age site on the Zululand Coast. S. Afr. J. Sci. 74: 70-71.

Huntley. B. J., 1977. Terrestrial ecology in South Africa. S. Afr. J. Sci. 73: $366-370$.

KeEt. J. D. M., 1936. Report on drift sands in South Africa. Department of Agriculture and Forestry Bulletin No. 172.

Macdonald. I. A. \& Pammenter. N. W., MS. Regeneration of a coastal dune forest following fire. Paper presented at the 5th Annual Congress, South African Association of Botanists, 1979.
MOLL. E. J., 1972. A preliminary account of the dune communities at Pennington Park, Mtunzini, Natal. Bothalia 10: $615-626$.

SChulze, B. R., 1965. Climate of South Africa Series Part 8. General Survey. Weather Bureau Publications. Pretoria: Department of Transport.

STEPHENS. H. B., 1939. Inspection of crown lands on Zululand coast between Richard's Bay and Sodwana Bay JulySeptember 1938. Department of Forestry, Pietermaritzburg.

VENTER. H. J. T., 1972. Die plantekologie van Richardsbaai, Natal. D.Sc. thesis. University of Pretoria.

WARD. C. J., 1980. The plant ecology of the Isipingo Beach Area, Natal, South Africa. Mem. bot. Surv. S. Afr. No. 45.

WeIsSER. P. J., 1978a. Changes in area of grasslands on the dunes between Richards Bay and the Mfolozi River 1937 to 1974. Proc. Grassld Soc. sth. Afr. 13, 95-97.

WEISSER. P. J., 1978b. A vegetation study of the Zululand dune areas. Conservation priorities in the dune area between Richards Bay and Mfolozi River Mouth based on a vegetation survey. Natal Town and Regional Planning Reports Vol 38, Pietermartizburg, 64pp.

WEISSER. P. J., 1979. Suitability of air-photo interpretation for monitoring coastal dune vegetation of the Zululand Dunes, South Africa. In The use of ecological variables in environmental monitoring. The National Swedish Environment Protection Board, Report PM 1151, 62-72.

WEISSER. P. J. \& MARQUES. F., 1979. Gross vegetation changes in the dune area between Richards Bay and the Mfolozi River, 1937-1974. Bothalia 12,4: 711-721.

Weisser, P. J., 1980. The dune forest of Maputuland. In M. W. Bruton \& K. M. Cooper, Studies on the ecology of Maputuland 78-90. Rhodes University, Grahamstown, and the Wildlife Society, Durban.

Weisser, P. J. Garland. I. F. \& Drews. B. K., 1982. Dune advancement 1937-1977 at the Mlalazi Nature Reserve. Mtunzini, Natal, South Africa, and a preliminary vegetation-succession chronology. Bothalia 14: 127-130.

WEISSER. P. J., 1982. Vegetation and conservation priorities in the dune area between Richards Bay and Mlalazi Estuary. Botanical Research Institute, Dept. of Agriculture. 